\title{
Microbial Forensics: Human Identification
}

\author{
Yong-Bin Eom ${ }^{\dagger ; *}$ \\ Department of Biomedical Laboratory Science, College of Medical Sciences, \\ Soonchunhyang University, Asan, Chungnam 31538, Korea
}

Microbes is becoming increasingly forensic possibility as a consequence of advances in massive parallel sequencing (MPS) and bioinformatics. Human DNA typing is the best identifier, but it is not always possible to extract a full DNA profile namely its degradation and low copy number, and it may have limitations for identical twins. To overcome these unsatisfactory limitations, forensic potential for bacteria found in evidence could be used to differentiate individuals. Prokaryotic cells have a cell wall that better protects the bacterial nucleoid compared to the cell membrane of eukaryotic cells. Humans have an extremely diverse microbiome that may prove useful in determining human identity and may even be possible to link the microbes to the person responsible for them. Microbial composition within the human microbiome varies across individuals. Therefore, MPS of human microbiome could be used to identify biological samples from the different individuals, specifically for twins and other cases where standard DNA typing doses not provide satisfactory results due to degradation of human DNA. Microbial forensics is a new discipline combining forensic science and microbiology, which can not to replace current STR analysis methods used for human identification but to be complementary. Among the fields of microbial forensics, this paper will briefly describe information on the current status of microbiome research such as metagenomic code, salivary microbiome, pubic hair microbiome, microbes as indicators of body fluids, soils microbes as forensic indicator, and review microbial forensics as the feasibility of microbiome-based human identification.

Key Words: Human identification, Massive parallel sequencing, Microbes, Microbial forensics, Microbiome

\section{서 론}

사람의 미생물군집(microbiome)은 신체의 부위마다 차 이가 있고 개인 간에도 차이가 있는 것 보고되었다 (Costello et al., 2009). 이것은 사람마다 고유의 미생물군집 을 가지고 있어 개인 식별의 수단으로 사용 가능성을 의 미한다(Blaser, 2010). Fierer 등은 컴퓨터 키보드와 마우스 에 남아 있는 미생물과 피부 세균을 분석하여 그 컴퓨터 를 사용한 사람을 확인하는 것이 가능하다고 발표하였다
(Fierer et al., 2010).

많은 사건들에서 가해자 또는 피해자의 몸에 남은 교 흔(bite mark)을 법과학적 증거로 채택하여 각 개개인마다 독특한 치아 배열을 법치의학적으로 분석하지만, 그 해석 은 주관적이며 어려움이 많다(Sweet and Pretty, 2001). 더군 다나 깨무는(biting) 과정에서 DNA가 전달되지만 타액 내 존재하는 수많은 정상 균무리와 효소들로 인해 DNA가 분해되어 시간이 경과할 수로 DNA 프로파일 전체를 확 보하기가 어렵다(Yaegaki et al., 1982; Sweet et al., 1997). 타 액에는 $1.4 \times 10^{8} / \mathrm{mL}$ 의 약 700 여종의 다양한 세균들이

Received: October 13, 2018 / Revised: December 11, 2018 / Accepted: December 12, 2018

*Professor.

${ }^{\dagger}$ Corresponding author: Yong-Bin Eom. Department of Biomedical Laboratory Science, College of Medical Sciences, Soonchunhyang University, 22 Soonchunhyang-ro, Shinchang-myeon, Asan-si, Chungcheongnam-do 31538, Korea.

Tel: +82-41-530-3039, Fax:+82-41-530-3085, e-mail: omnibin@ @sch.ac.kr

(C) The Korean Society for Biomedical Laboratory Sciences. All rights reserved.

@This is an Open Access article distributed under the terms of the Creative Commons Attribution Non-Commercial License (http://creativecommons.org/licenses/by-nc/3.0/) which permits unrestricted non-commercial use, distribution, and reproduction in any medium, provided the original work is properly cited. 
존재한다(Lazarevic et al., 2010). 타액의 미생물군집은 구강 의 위생상태, 식습관 등에 의해 영향을 받기 때문에 구강 미생물을 개인 식별에 적용하기에는 어려움이 있지만, 사 건 발생 24시간 후까지도 피부와 의류 상의 교흔에서 살 아있는 세균이 발견되었다(Brown et al., 1984; Borgula et al., 2003; Rahimi et al., 2005). 그러나 이들 구강 미생물 대부분 이 in vitro에서 배양되지 않기 때문에 타액의 미생물군집 을 법과학적으로 사용하기 위해서는 대용량 염기서열 결 정법 등의 적용이 필요하다(Ahn et al., 2011).

피부의 세균들은 세포벽을 가지고 있는 세균 구조의 특 성상 외부 환경 스트레스(습도, 온도, 자외선 노출) 등에 강한 저항성을 가지고 있기 때문에 접촉한 표면에 오랜 기간 지속될 수 있다(Smith et al., 1996; Brooke et al., 2009). 따라서 우리의 일상활동 동안에 접촉하는 물체의 표면에 피부와 연관된 미생물군집의 추적이 법미생물학적으로 응 용될 수 있다. 두 사람의 손바닥 표면 세균의 계통발생형 이 단지 $13 \%$ 만 유사하고(Fierer et al., 2008), 신체 다른 부 위의 피부에서도 사람간 차이를 보였다(Costello et al., 2009; Grice et al., 2009). 또한 손을 씻은 후 몇시간 안에 손바닥 표면의 세균군집이 복구되고, 수개월의 기간을 두고 시료 를 채취해도 사람간 미생물군집의 다양성이 관찰되었다 (Fierer et al., 2008; Costello et al., 2009; Grice et al., 2009).

사건 현장 증거물의 표면에 혈흔, 정액, 타액 등이 발견 되지 않을 경우, STR 분석에 의한 DNA 프로파일을 확보 할 수 없는 때에는 피의자 또는 피해자의 피부 표면에 풍 부하게 존재하는 미생물을 법미생물학적으로 분석하는 것이 접촉 표면의 미세 증거인 사람 $\mathrm{DNA}$ 분석보다 세균 DNA를 확보하기가 용이하다(Fredricks, 2001). 또한 의류, 얼룩진 표면, 고도의 거친 표면 같이 명확한 지문을 획득 하기 어려운 물체의 경우 법미생물학적 분석법이 유용할 것이다. 그리고 기존 DNA 프로파일 분석으로는 개인 식 별이 불가능했던 한계점인 일란성 쌍둥이(identical twins) 도 서로 다른 미생물군집을 가지고 있으므로 법미생물학 적 개인 식별의 적용 가능성이 있다(Turnbaugh et al., 2009).

현재 사용되고 있는 STR 프로파일 분석은 아주 적은 (low copy number) 양의 DNA, 분절된 DNA, 혼합 및 부 분 프로파일로 인해 법과학적 개인 식별이 어려운 경우 가 있다. 이러한 경우 대체 방법으로 사람 미생물군집은 다른 높은 복제 수 유전 마커의 한 예이며, 미생물 세포는 인간 세포에 1:1 (Sender et al., 2016) 10:1 (Savage, 1977) 의 비율로 존재하기 때문에, 부분적이거나 결론 내릴 수 없는 STR 프로파일을 보완할 수 있는 잠재적 표적이 될
수 있다.

본 리뷰 논문에서는 인간 미생물군집 프로젝트(human microbiome project)의 연구결과물이 미생물학과 의학 분야 에 기여할 뿐만 아니라(Turnbaugh et al., 2007), 법과학분야 에 적용함으로써 기존 DNA 프로파일 및 지문 분석법의 보완 및 대안으로서 사람마다 독특하고 안정적으로 전달 가능한 미생물군집을 법미생물학적 분석을 통한 개인 식 별의 가능성에 대해 살펴보고자 하였다.

\section{본 론}

\section{메타유전체 코드(Metagenomic code)}

최근의 인간 미생물군집에 대한 대규모 연구들은 건강 한 개체를 대상으로 신체 부위 별로 특별한 커뮤니티 구 조와 미생물의 기능에 큰 다양성을 보여주었다(Qin et al., 2010; Human Microbiome Project, 2012). 또한, 인간 미생물 군집의 특징은 상당한 기간 동안 안정적으로 개인과 연관 될 수 있음이 밝혀졌다(Fierer et al., 2010; Faith et al., 2013; Schloissnig et al., 2013). 이러한 연구결과는 개개인이 내재 된 미생물군집에 기초하여 인구 집단 내에서 유일하고 안 정적으로 확인될 수 있음을 시사한다(Fig. 1). 동시에 인간 미생물군집은 사람 개체 자신의 유전체를 넘어서는 유전 적 변이의 저장소로도 볼 수 있고, 인간 미생물군집의 식 별 가능한 정도는 법유전학과 유전체 정보와 관련이 있다. 사람들은 인구 집단으로부터 구별될 수 있는 독특한 "미 생물 지문(microbial fingerprint)"을 가지고 있고, 특히 장내 미생물군집의 경우 수년이 지난 후까지도 개개인마다 독 특한 미생물군집이 유지되어 개인 식별에 활용될 수 있다 (Yatsunenko et al., 2012).

사람 유전체에 있는 단일 뉴클레오타이드 다형성(SNPs) 은 단기 일련 반복(STRs)과 마찬가지로 강력한 개인 식별 력을 가지고 있어, 약 30 80개의 SNPs을 분석하면 지구 상의 개개인을 개인 식별할 수 있다(Lin et al., 2004). 또한 SNPs 분석은 신체적 특징, 질병의 위험도, 인구 동태 통계 학, 가족력 등에 관한 개체의 특성을 예측하는데도 이용될 수 있다(Lowrance and Collins, 2007; Greenbaum et al., 2011; Rodriguez et al., 2013). 사람 SNPs가 개인의 특징을 분석하 는데 사용될 수 있는 것과 같이, 인간 미생물군집도 식습 관(Wu et al., 2011), 건강상태(Greenblum et al., 2012), 나이와 지리학적 위치(Yatsunenko et al., 2012) 등 개체의 다양한 특징과 연관되어 있다고 보고되었다.

인구 집단에서 특정 개인을 식별할 수 있는 메타유전체 


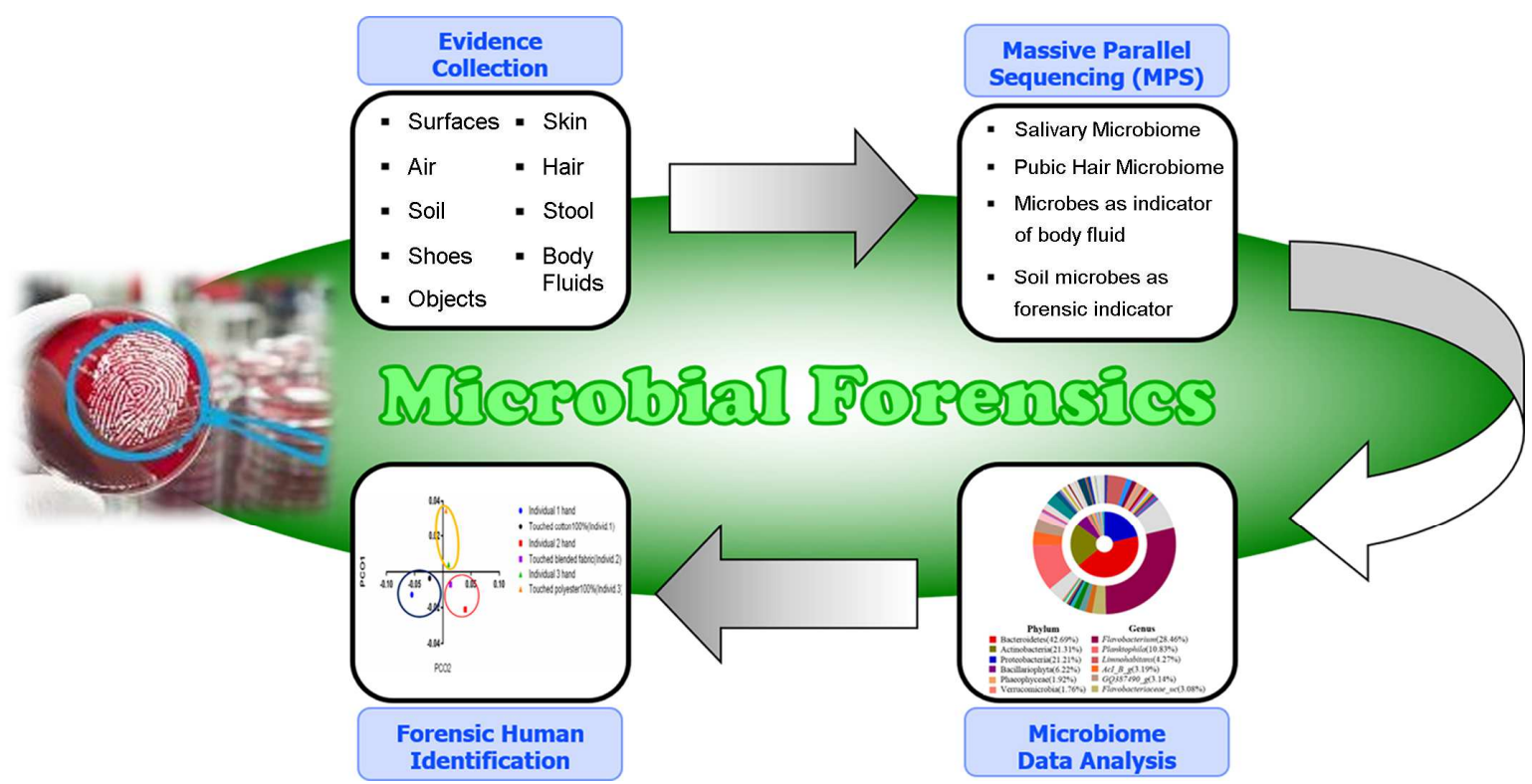

Fig 1. Microbial forensics and human identification. A simplified schema summarizing the forensic microbiome analysis pathway including: collecting samples from various reservoirs of microbiomes (Evidence Collection); the different sequencing targets available to analyze the microbiomes (Massive Parallel Sequencing); and data analysis and human identification (Microbiome Data Analysis and Forensic Human Identification).

코드는 시간이 지난 뒤에도 다시 검출될 수 있어야 하고, 실수로 다른 사람을 잘못 식별하지 않아야 한다. 개개인 마다 독특하고 최대로 안정적인 메타유전체의 특징으로 부터 메타유전체 코드를 구성하여 미생물군집을 법과학 적 개인 식별에 이용 가능함이 제시되었다(Franzosa et al., 2015). Franzosa 등은 개인화된 메타유전체 코드를 구성할 수 있는 네 가지 유형의 메타유전체 기능을 고려했는데, $16 \mathrm{~S}$ 리보좀 유전자 염기서열 결정법에 의한 operational taxonomic unit (OUT)와 whole metagenome shotgun (WMS) 염기서열 결정법으로 분석된 세균 및 고세균 종의 풍부함 을 두 개의 유형으로 분류군 수준으로 분석하였다. 또한, MetaPhlAn 데이터베이스로부터 균종 특이 마커 유전자 와 박테리아 참조 유전체의 큰 세트에서 가져온 kilobase windows (kbwindows) 두 가지 유형의 유전자 수준으로도 분석하였다(Segata et al., 2012). 이러한 메타유전체 코드를 활용해서 특정 사람과 연관된 미생물군집이 인구 집단으 로부터 개인을 식별할 수 있는 균주 레벨의 다양성이 충 분히 있음을 확인하였고, 시간이 경과하더라도 미생물군 집 분석으로 개인 식별이 가능함을 보여주었다(Franzosa et al., 2015).

\section{타액 미생물군집(Salivary microbiome)}

지금까지 법과학적 개인 식별은 사람 DNA 프로파일 분석에 의존하여 왔다. 그러나 사람 DNA 증거물에는 여 러가지 제한점들이 있는데, 사건 현장에서는 자외선, 고 열, 습기 등에 의한 부패로 인해 DNA가 쉽게 분해(degradation)되거나 발견되는 DNA의 양이 극미량(low copy number)이어서 전체 STR 프로파일을 확보하기 어렵다는 한계점이 있다. 또한 기존 DNA 프로파일 분석으로는 일 란성 쌍둥이를 구별할 수 없다는 문제점이 있다. 이러한 한계점을 극복하기 위해 미생물군집 분석이 대안이 될 수 있는데, bacterial DNA는 human DNA에 보다 잘 보전되고 쉅게 분해되지 않고, 미생물군집 분석을 통해 일란성 쌍둥 이를 식별할 수 있다는 장점이 있다(Stahringer et al., 2012). 환경에서 발견되는 미생물의 $99 \%$ 가 배양되지 않는 것으 로 추정되지만(Handelsman, 2004), 대용량 병렬 염기서열 결정법(massive parallel sequencing; MPS)을 사용하여 미생 물군집을 분석할 수 있기 때문에 환경 미생물의 분리 배 양 없이도 분석이 가능하게 되었다.

이러한 대용량 병렬 염기서열 결정법(MPS)을 사용하여 타액의 미생물군집을 연구한 결과들이 많이 보고되었다 (Aas et al., 2005; Costello et al., 2009; Lazarevic et al., 2009; 
Zaura et al., 2009; Lazarevic et al., 2010; Caporaso et al., 2011; Stahringer et al., 2012). MPS에 의한 미생물군집 분석의 주 요 표적 유전자는 $16 \mathrm{~S} \mathrm{rRNA}$ 인데 이것은 미생물의 생명 현상 유지에 필수 불가결하고 모든 미생물들이 가지고 있기 때문이다(Weisburg et al., 1991; Case et al., 2007). 그러나 $16 \mathrm{~S}$ rRNA 표적 유전자는 유전체 내 이질성(intra-genomic heterogeneity), 모자이크 현상(mosaicism), 보편적인 염기서 열 식별 값의 부족 등의 한계점들이 있다(Rajendhran and Gunasekaran, 2011). 이러한 한계점을 극복하고 보다 완전 한 미생물군집을 분석하기 위해 미생물에서 고도로 보전 되고 가장 중요한 효소인 RNA 중합효소의 beta 아단위 를 암호화하는 $r p o B$ 유전자를 표적으로 사용하기도 한다 (Boor et al., 1995). rpoB 유전자의 초변이 구역은 미생물을 종(species)과 아종(subspecies) 레벨까지 동정할 수 있다는 장점이 있다(Mollet et al., 1997; Adekambi et al., 2003; La Scola et al., 2006).

타액에 존재하는 주요 미생물로 Streptococcus 균종(species)의 서로 다른 균주(strains)들을 사람은 가지고 있고, 이 균주들은 사람마다 독특하게 존재한다(Rudney and Larson, 1994; Wisplinghoff et al., 1999). 이들을 분석하기 위 해서 $16 \mathrm{~S}$ rRNA만을 표적으로 할 경우 이러한 사람마다 독특한 미생물 균주들을 검출할 수 없지만, $r p o B$ 와 $16 \mathrm{~S}$ rRNA 두 가지 유전자를 표적으로 할 경우 이러한 미생물 균주 모두를 보다 심도 깊게 동정할 수 있다. 특히, $16 \mathrm{~S}$ $\mathrm{rRNA}, r p o B 1, r p o B 2$ 세 가지 유전자를 표적으로 한 대용 량 병렬 염기서열 분석이 균종 및 균주 레벨까지 구별할 수 있어 개인 식별의 가능성을 제시하였다(Leake et al., 2016).

범죄현장에서 발견되는 정액 및 혈액 등과 달리 타액 은 $1 \mathrm{~mL}$ 당 약 5 억개의 미생물들이 있고 적어도 700 개의 서로 다른 미생물 균종들이 존재한다(Paster et al., 2006). 각 개개인 사이에 타액 미생물군집의 차이가 있다는 연구 (Costello et al., 2009; Human Microbiome Project, 2012) 뿐만 아니라, 타액 미생물군집은 수개월 동안 안정성이 유지 되는 것을 보여주었다(Lazarevic et al., 2010; Leake et al., 2016). 타액에서 발견되는 공통적인 미생물은 Firmicutes, Proteobacteria, Actinobacteria, Bacteroides, Fusobacteria 등이 었다(Lazarevic et al., 2009; Lazarevic et al., 2010; Stahringer et al., 2012). 그러나 타액은 역동적으로 흐르는 특성 때문에 타액 미생물군집에는 자연적인 변이가 있고 몇몇 미생물 들은 항상 일정하게 검출되지 않을 수도 있다. 이러한 제 한점을 극복하기 위해 시퀀싱 리드 20 개 이하는 분석 전
에 제거하고, $16 \mathrm{~S} \mathrm{rRNA}$ 와 $r p o B$ 유전자를 동시에 표적으로 하여 분석함으로써 개인 내 변이를 최소화할 수 있다.

Stahringer 등은 12 24세 사이의 일란성 쌍둥이 타액 미 생물군집이 다른 쌍과 비교하여 통계학적으로 유사하지 않다는 것을 보여주었는데, 이것은 타액 미생물군집에 유 전적 영향이 거의 없고 환경적 요인(식습관, 구강 위생상 태, 흡연, 음주, 약 복용 여부)에 의해 차이가 발생하는 것 을 의미한다(Stahringer et al., 2012). 따라서 어떤 사람의 타액 미생물군집을 분석함으로써 그 사람의 생활습관에 관한 정보를 추정하는 것이 가능할 것이다. 또 다른 환경 요인으로 항생제 복용 여부가 타액 미생물군집에 영향 을 미칠 수 있다. Lazarevic 등은 급성 중이염 환자에게 amoxicillin 치료가 타액 미생물군집의 조성 변화에 영향을 주어 균종의 풍부함과 다양성에 변화를 가져올 수 있음을 확인하였다(Lazarevic et al., 2013). 그러나 항생제 치료가 끝나고 3 주 후에는 미생물군집 조성이 치료 전의 다양성 으로 복귀된다. 그러므로 범죄 현장의 타액 증거물에서 특정 항생제 성분의 존재 여부를 분석하여 항생제 물질이 확인되면, 이 후 용의자로부터 타액 참조 시료(reference sample)를 채취하기 전에 같은 항생제를 복용시킨 후 타 액 시료를 채취하여 미생물군집을 분석함으로써 개인 식 별의 가능성을 높일 수 있을 것이다. 또한 타액 증거물에 서 항생제 성분이 검출되지 않았는데, 용의자가 항생제를 복용하고 있는 경우, 항생제 치료가 끝나고 타액 미생물 군집의 다양성이 복귀된 이후 참조 시료를 채취할 필요성 이 있다(Leake et al., 2016).

\section{음모 미생물군집(Pubic hair microbiome)}

성폭력 또는 성추행 사건에서 피해자의 질 도말 등의 증거물에서 가해자의 정액 검출과 정자의 DNA 프로파일 분석을 통해 성범죄 수사가 이루어져 왔다. 그러나 단순 성추행, 콘돔의 사용 또는 체외 사정, 무정자증의 경우 정 자가 발견되지 않아서 성폭력의 직접적인 증거를 확보하 기 어려운 경우가 종종 있다(Bai et al., 2012; Mayntz-Press et al., 2008). Y-STR 검사는 피해 여성 DNA가 많이 존재하 는 증거물에서 남성 $\mathrm{DNA}$ 의 존재를 확인할 수 있고, 성 교 후 5 6일이 지나 핵 DNA 타이핑이 불가능한 경우 에도 남성 DNA를 검출할 수도 있다(Mayntz-Press et al., 2008). 미토콘드리아 DNA (mitochondria DNA; tuna)는 모 발에 핵 DNA가 극미량 존재하기 때문에 핵 DNA 타이핑 으로 분석이 되지 않는 경우에 모계 혈연관계를 분석하는 데 아주 유용하다(Pfeiffer et al., 1999; Budowle et al., 2003). 
Table 1. Microorganisms as forensic indicators in the microbial forensics

\begin{tabular}{|c|c|c|}
\hline Specimens & Microorganisms & References \\
\hline Saliva & $\begin{array}{l}\text { Streptococcus spp., Firmicutes spp., } \\
\text { Proteobacteria spp., Actinobacteria spp., } \\
\text { Bacteroides spp., Fusobacteria spp. }\end{array}$ & $\begin{array}{l}\text { Rudney and Larson, 1994; Wisplinghoff et al., 1999; } \\
\text { Nakanishi et al., 2009; Lazarevic et al., 2010; } \\
\text { Stahringer et al., 2012 }\end{array}$ \\
\hline Vaginal secretions & Lactobacillus crispatus, Lactobacillus gasseri & Akutsu et al., 2012; Fleming and Harbison, 2010 \\
\hline Pubic hairs & $\begin{array}{l}\text { Lactobacillus iners, Prevotella spp., } \\
\text { Aggregibacter segnis }\end{array}$ & Tridico et al., 2014 \\
\hline
\end{tabular}

Y-STR은 부계 유전, mtDNA는 모계 유전에 관련된 사건 분석에 사용되지만, 혼합 DNA의 경우 해석에 상당한 어 려움이 있다.

두모(scalp hair)와 음모(pubic hair)의 미생물군집을 분석 하여 7명의 개인에서 두모와 음모의 차이와 개인 식별이 가능하다고 보고되었다(Tridico et al., 2014). 음모의 미생물 군집은 시간이 지나도 안정하고 성별에 대한 정보도 제공 할 수 있으며, 커플 사이의 음모 미생물군집의 유사성은 커플이 동거하며 성접촉을 통해 음모의 미생물군집이 상 호 교환된 결과라고 하였다(Tridico et al., 2014). 이러한 미 생물군집의 프로파일 분석은 성폭력 사건에서 피의자와 피해자 사이에 어떤 증거물의 전달 여부를 결정하는 새 로운 분석도구로서 사용될 수 있을 것이다(Williams and Gibson, 2017). 증거물의 다양한 보관 조건(냉장, 냉동, 에 탄올에 담금, FTA 카드에 보관, RNAlater에 담가 보관) 등 이 보관 시간보다 영향을 많이 미치지만(Bai et al., 2012; Hale et al., 2015), 두모의 미생물군집 프로파일은 보관 온도와 시간에 의해 크게 영향을 받지 않는다고 하였다 (Williams and Gibson, 2017). 따라서 성폭력 및 성추행 사건 에서 피의자의 DNA가 검출되지 않을 경우 음모의 미생 물군집 프로파일 분석이 법과학적 조사에 기여할 것으로 사료된다. 신체 부위 별 주요 미생물 분포를 이용하여 법 미생물학적 분석에 활용한 연구를 Table 1 에 정리하였다 (Table 1).

\section{법의학 지표로서 미생물(Microbes as forensic indicator)}

미생물에는 세균, 곰팡이, 조류, 기생충, 바이러스, 프리 온 등을 포함한다. 이러한 미생물은 지상 및 수중 환경 등 의 도처에 풍부하게 존재한다. 도처에 존재하고 다양성이 풍부하다는 의미는 미생물이 법과학적 증거로서 유용성이 있다는 의미이다(Budowle et al., 2010). 사람의 체내와 체표 면에는 사람의 세포보다 10 배 이상 많은 미생물이 살고 있
다(Turnbaugh et al., 2009). 미생물은 의학, 생태학, 발효 과 학 분야에서는 그 중요성이 인지되어 왔지만, 법과학자들 에게는 그리 중요하게 인식되지 않았었다. 그러나 2001년 에 미국에서 발생한 911 테러 이후 탄저균 아포 편지봉 투를 이용한 생물테러 공격으로 22 명의 무고한 시민들이 감염되었고, 11 명은 피부 탄저병에 또 다른 11 명은 폐 탄저병으로 고통받다가 그 중 5명이 사망하게 되면서부 터 법미생물학(microbial forensics)의 필요성이 제기되었다 (Jernigan et al., 2002; Read et al., 2002). 대용량 염기서열 분 석법과 생물 정보학 등의 발전에 힘입어 미생물군집에 대 한 법과학적 분석이 가능하게 되었다(Li et al., 2012; Segata et al., 2012). 이제는 미생물을 동정하기 위해서 더 이상 배양할 필요가 없으며 메타유전체학(metagenomics)으로 수백 수천종의 미생물 특성을 분석할 수 있게 되었다 (Human Microbiome Project, 2012; Yatsunenko et al., 2012). 또한, 특정 균종과 플라스미드의 연쇄 전달을 효율적으로 연구하는 것이 가능하게 되었다(MacConaill and Meyerson, 2008; Nakamura et al., 2008; Pallen and Loman, 2011).

법미생물학은 미생물을 이용하여 법과학적 조사를 하는 것으로 특정 미생물군집의 존재 여부를 통해 어떤 개인, 유기체, 무기체, 위치 등을 파악하는데 사용될 수 있게 되었다(Harmon, 2005). 미생물은 무모하게 또는 악의적으 로 전파될 수 있기 때문에 피고인과 원고를 특정 균종과 연결시켜는 것이 필요할 때가 있다. 미생물 대사 능력의 다양성으로 인해 대부분의 유기질과 무기질이 미생물의 활동으로 변경될 수 있고 이것은 법과학적 증거물의 보 존에도 영향을 미칠 수도 있다. 사건 현장의 변시체는 감 염성 미생물의 근원이 될 수 있기 때문에 법과학적 조사 를 하는 현장 과학수사요원들은 항상 감염의 위험성을 인 지해서 생물 안전에 만전을 기해야 한다(Malik and Singh, 2011). 


\section{체액 지표로서 미생물(Microbes as indicators of body fluids)}

법과학 증거물에서 질액, 타액, 정액, 혈액과 같은 체액 의 검출을 위한 검사법들이 개발되어 있으나 정확도가 그 리 높지 않은 편이다(Gunn, 2018). 이들 기존의 검사법들 은 질액과 타액을 확실하게 구별할 수 없는 경우가 있는 데, 이는 성폭행 사건이 일어난 순서의 혐의를 뒷받침하 는 중요한 고려 사항일 될 수 있기 때문에 사건을 밝히는 데 어려움을 초래할 수 있다. 예를 들어 정액과 질액 둘다 양성인 검사결과는 질내 삽입의 성폭력을 의미한다(Gunn and Pitt, 2012).

질내 미생물무리(microflora)는 다양한 세균들로 구성되 어 있지만 Lactobacillus 균속에 속하는 몇몇 균종이 우세 하게 존재한다(Jespers et al., 2012). 한때 모든 여성은 유일 하고 독특한 균무리를 가진다고 제시되었지만(RedondoLopez et al., 1990), 지금은 그렇지 않다고 생각되고 있다 (Lamont et al., 2011). 하지만, 질내 미생물군집이 인종 집단 사이에 차이가 있다는 것이 밝혀졌다(Ravel et al., 2011). 또한 Lactobacillus crispatus로부터 유전자 마커를 검출하는 것이 질액을 확인하는 신뢰할 만한 표지자가 될 수는 있 지만 다른 균종에서는 적합하지 않다는 연구결과가 있다 (Fleming and Harbison, 2010; Akutsu et al., 2012). 반면에 손, 사타구니, 음경에서도 Lactobacillus crispatus DNA가 검출 될 수 있기 때문에 단일 균종만으로 질액을 확인하는 것 보다 수많은 균종들을 검출하기 위한 마크로어레이 분석 을 사용하는 것이 적합하다고 주장하였다(Benschop et al., 2012).

구강 내 사슬 알균들을 검출하여 타액을 확인하는 방 법이 제시되었는데, PCR 기법을 사용하여 Streptococcus salivarius와 Streptococcus mutans 균종들을 타액에서는 확 인하였지만 질액에서는 이 두 균종 모두 발견되지 않았 다고 하였다(Nakanishi et al., 2009). 그러나 이들 두 균종이 비록 낮은 비율로 존재하지만 질내에서도 집락을 형성하 는 것으로 밝혀졌다(Rabe et al., 1988).

충격에 의해 흩뿌려진 작은 혈흔과 숨을 내쉴 때 함께 나온 혈흔을 구별하는 것은 매우 어렵지만, 이것은 죽어 가는 외상을 입은 희생자를 돕기 위한 사람의 의류에 희 생자가 숨을 내쉴 때 함께 나오는 미세한 분무 혈흔이 묻 을 수 있고, 또한 가해자가 폭행하는 동안에도 비슷한 혈 흔이 묻을 수 있기 때문에 이것을 구별하는 것은 매우 중 요하다(James et al., 2005; Gardner, 2012). 숨을 내쉴 때 나오
는 혈흔은 공기방울을 포함하고 있지만 충격에 의해 흩 뿌려진 혈흔에서는 공기방울이 포함되어 있지 않다. 하지 만 면재질의 의류같이 흡수성 표면에 혈액이 떨어지면 이 것을 구별하기 쉽지 않다. 숨을 내쉴 때 함께 나온 혈흔에 는 타액이 혼합되어 있기 때문에 타액의 세균들이 오염되 어 있을 수 있다(Donaldson et al., 2010). 구강 내 미생물군 집 중에서 사슬 알균이 우세한 균종이지만 환경에 노출되 면 오랜 기간 생존할 수 없다(Tagg and Ragland 1991). 하지 만, 이들 균종으로부터의 DNA를 포함하는 혈액을 흡수성 섬유에 묻히고 나서 2 3개월 후에도 구강 내 사슬 알균 DNA가 검출 가능하였다는 보고가 있다(Donaldson et al., 2010; Power et al., 2010). 재채기를 하는 동안 함께 흩뿌 려진 혈흔의 경우 타액과 다른 코에 포함된 또다른 미생 물군집이 존재하기 때문에 여러 가지 세트의 primers 사용 이 필요하다(Lemon et al., 2010).

\section{법의학 지표로서 토양 미생물(Soils microbes as foren- sic indicator)}

토양은 어떤 사람, 동물 또는 식물을 특정 지리적 위치 와 연결할 수 있는 유용한 법의학적 지표이다(Tibbett and Carter, 2008; Ruffell, 2010; Nikhil et al., 2014). 토양의 광물질 과 화학적 구성 성분의 분석은 때에 따라 상당히 많은 양 의 토양이 필요하거나 토양 데이터베이스가 없는 경우 제 한점이 된다(Zala, 2007).

모든 토양은 극도로 다양한 미생물군집을 포함하고 있 지만 대부분의 균종들은 실험실에서 배양되지 않는다. 분 자생물학 기법의 발달로 이러한 비배양 문제는 더 이상 문제가 되지 않고 법의학 지표로서 토양 미생물의 잠재성 을 연구하는 수많은 연구가 있었다(Giovannoni et al., 1990; Torsvik et al., 1990; Li et al., 2012; Segata et al., 2012; Lee and Eom, 2016). 말단 제한 효소 길이 다형성(terminal restriction fragment length polymorphism; T-RFLP)를 활용한 $16 \mathrm{~S}$ ribosomal RNA 유전자 염기서열 분석법이 사용되거나(Smalla et al., 2007; Macdonald et al., 2011; Quaak and Kuiper, 2011), 증폭산물 길이 이질성-다중 중합효소 연쇄반응(amplicon length heterogeneity-polymerase chain reaction; ALH-PCR) 기 법이 사용되었다(Moreno et al., 2006; Moreno et al., 2011). 토 양 미생물의 풍부함은 매우 적은 양의 토양 증거물만 필 요하다는 것을 의미하고, 분석 기법들이 상대적으로 저렴 하고 자동화 될 수 있다는 장점이 있다. 그러나 토양 미생 물을 분석하는 것은 짧은 거리의 지역과 계절에 걸쳐 토 양 미생물군집에 주요 변화가 있을 경우 이런 분석법의 
신뢰성은 영향을 받을 수 있다는 한계점이 있다(Ritz et al., 2009). 이러한 한계점을 극복하기 위해 질소 고정 근류균 (rhizobia) 같은 토양 미생물을 표적으로 하려는 연구가 시 도되었다(Lenz and Foran, 2010).

\section{미생물 지문을 이용한 개인 식별}

상당히 오랜 기간이 지났음에도 불구하고 미생물 지문 (microbial fingerprints)으로 큰 인구 집단에서 특정 개인을 식별할 수 있는 가능성이 보고되었다(Franzosa et al., 2015; Leake et al., 2016). 피부 박테리아 프로파일이 수개월이 지 난 후에도 특정한 개인과 그것을 접촉했던 물체 사이의 연관성을 밝히는데 사용될 수도 있다(Wilkins et al., 2017). 특정 미생물군집 시그널에 기초하여 화장실, 문손잡이, 화 장실 바닥과 같이 서로 다른 대상에서 사람의 장관, 피부 및 토양 세균 프로파일의 특이 생물지리학적 패턴을 정의 하는 것도 가능하다(Flores et al., 2011). 특정 신체 부위에 의한 어떤 사람의 미생물군집 개별화는 법과학적 수사 증 거로 유용할 수 있다. 예를 들어, 희생자에게 피의자에 의 해 남겨진 미생물군집은 특정 신체 부위와 성폭력 범죄의
연관성을 밝힐 수 있게 한다. DNA 증거가 없는 경우, 미 생물 지문은 특정 신체 부위와 범죄의 연관성뿐만 아니라 특정 개인의 범죄 관련성을 밝히는데도 유용하다.

개인 식별 목적의 미생물 지문의 역량은 민족 집단을 추정하는데 까지 적용될 수도 있다. 미토콘드리아 DNA (mtDNA) 일배체형과 미토콘드리아 단일 뉴클레오타이드 다형성(mtSNPs)을 결합시킨 연구는 동일한 분변 및 질 샘 플로부터의 미생물군집 프로파일링 분석과 함께 미생물군 집 패턴이 숙주의 조상 유전체 배경과 연관될 수 있음을 보여주었다(Ma et al., 2014). 이러한 연구들은 법의학 관련 시료의 미생물 및 심지어 비-미생물 DNA 지문도 단일 개체 및 하위 개체를 정확하게 구별할 수 있으며 잠재적 인 물리적 증거의 출처(대상)와 연결할 수 있음을 제시하 는 것이다. 법과학 문헌들이 미생물 유래 데이터(Damann et al., 2015), 특유의 시그니처(Can et al., 2014) 및 법의학 지 표(Alan and Sarah, 2012)의 잠재적인 유용성에 관해 보고하 고 있다. 법의학 지표의 예로는 신원 확인, 출신 국가 및 사망 시각 추정 등이 있다.

최근 Schmedes 등은 법과학적 개인 식별을 위해 피부

Table 2. Microbial markers present on the hand, foot, manubrium for body site classification

\begin{tabular}{|c|c|c|c|}
\hline Body site & Microbial markers & Accuracy $(\%)$ & References \\
\hline \multirow{5}{*}{ Hand } & Propionibacterium acnes & \multirow{5}{*}{$95.8 \sim 100 \%$} & \multirow{5}{*}{ Schmedes et al., 2018} \\
\hline & Propionibacterium granulosum & & \\
\hline & Propionibacterium humerusii & & \\
\hline & Propionibacterium phage P1 1 & & \\
\hline & Propionibacterium phage $\mathrm{P} 100 \mathrm{~A}$ & & \\
\hline \multirow{5}{*}{ Foot } & Propionibacterium phage PAD20 & \multirow{5}{*}{$54.2 \sim 83.2 \%$} & \multirow{5}{*}{ Schmedes et al., 2018} \\
\hline & Propionibacterium phage PAS50 & & \\
\hline & Propionibacterium sp. $434 \mathrm{HC} 2$ & & \\
\hline & Propionibacterium sp. 5 U 42AFAA & & \\
\hline & Propionibacterium sp. HGH0353 & & \\
\hline \multirow{10}{*}{ Manubrium } & Propionibacterium sp. KPL1844 & \multirow{10}{*}{$70.8 \sim 95.8 \%$} & \multirow{10}{*}{ Schmedes et al., 2018} \\
\hline & Propionibacterium sp. KPL1854 & & \\
\hline & Propionibacterium sp. KPL2008 & & \\
\hline & Rothia dentocariosa & & \\
\hline & Corynebacterium jeikeium & & \\
\hline & Corynebacterium pseudogenitalium & & \\
\hline & Corynebacterium tuberculostearicum & & \\
\hline & Corynebactrium sp. HFH0082 & & \\
\hline & Corynebactrium sp. KPL1818 & & \\
\hline & Corynebactrium sp. KPL1824 & & \\
\hline
\end{tabular}


미생물군집으로부터 계통 분기 특이 마커의 염기서열을 분석하여 286개의 미생물 과, 속, 종 및 아종 수준의 마 커로 구성된 hidSkinPlex를 개발하여 $94 \%$ 정확도로 개인 식별이 가능하며, 평균 $86 \%$ 정확도로 특정 신체 부위를 예측할 수 있음을 보고하였다(Schmedes et al., 2018). 또한 그들은 hidSkinPlex에서 Propionibacterium acnes, Propionibacterium granulosum, Propionibacterium humerusii, Propionibacterium phage P1 1, Propionibacterium phage P100 A, Propionibacterium phage PAD20, Propionibacterium phage PAS50, Propionibacterium sp. 434 HC2, Propionibacterium sp. 5 U 42AFAA, Propionibacterium sp. HGH0353, Propionibacterium sp. KPL1844, Propionibacterium sp. KPL1854, Propionibacterium sp. KPL2008, Rothia dentocariosa, Corynebacterium jeikeium, Corynebacterium pseudogenitalium, Corynebacterium tuberculostearicum, Corynebactrium sp. HFH0082, Corynebactrium sp. KPL1818, Corynebactrium sp. KPL1824 등의 미 생물 마커를 분석하여 손에서는 95.8 100\%(평균 97.9\%, 표준편차 $2.1 \%$ ), 발에서는 $54.2 \sim 83.2 \%$ (평균 $73.22 \%$, 표 준편차 $7.5 \%$ ), 복장뼈 자루피부에서는 70.8 95.8\%(평균 $86.3 \%$, 표준편차 $6.9 \%$ ) 정확도로 각각의 신체 부위를 구 분할 수 있었다(Table 2).

\section{결 론}

사람의 미생물군집은 건강, 신체 대사, 면역반응에서 중 요한 역할을 하고(Cho and Blaser, 2012), 인체의 유전적 구 성에도 크게 기여한다. 인체에 미생물군집의 집락 형성은 출생과 함께 시작되어 성장하는 동안 지속적으로 변화하 게 된다(Capone et al., 2011; Bokulich et al., 2016). 개개인 마 다 독특한 유전적 및 환경적 요소는 미생물군집을 형성하 는데 도움을 주며, 따라서 미생물군집은 개개인마다 유일 할 수 있다. 시간이 지남에 따라 안정화될 수 있는 균주 특이 서명과 같은 개인 미생물의 특징은 미생물군집 특성 을 잠재적으로 법의학 개인 식별에 적용 가능하게 한다 (Franzosa et al., 2015; Oh et al., 2016; Brandwein et al., 2018).

그러나, 법미생물학적 분석 기법의 개인 식별에 적용은 아직 초기 단계이고, 인종 집단간 미생물군집의 차이가 있기 하지만 어떤 개인의 미생물군집이 유전(Turnbaugh et al., 2009), 나이 및 거주 장소(Yatsunenko et al., 2012), 가족 (Song et al., 2013), 애완동물(Misic et al., 2015), 식습관(David et al., 2014), 흡연 여부(Bizzarro et al., 2013; Moon et al., 2015), 키스(Kort et al., 2014), 건강(Casarin et al., 2013) 및 위
생(Fierer et al., 2008) 상태 등에 의해 다양할 수 있기 때문 에 보다 많은 정보를 필요로 한다. 또한 개인 식별과 지리 학적 위치 추정의 법의학적 지표로서 미생물군집의 유효 성에 관한 연구가 필요하다. 법미생물학 분야는 생물 범 죄 및 생물 테러 등의 위해성 미생물 분석에 초점을 두었 다가 이제는 다양한 미생물군집 응용 분야로 확장되었으 며(Schmedes et al., 2016), 향후 연구에서는 미생물군집 프 로파일링이 법과학적 조사 방법으로 적극적으로 사용되 기 이전에 유효성 확인 기준을 확립하고, 미생물군집 데 이터를 보다 정확하게 해석하고 표준을 확립하기 위한 방 법 개발 및 새로운 통계 모델을 고려해야 한다.

미생물군집 프로파일 분석에는 현재 2 가지 주요 방법 이 있는데, 가장 일반적으로 사용되어온 방법은 $16 \mathrm{~S}$ ribosomal RNA 단일 마커의 염기서열 분석법이었으나 근래에 는 전체 미생물군집(whole microbiome)의 shotgun sequencing 기법이 널리 사용되고 있다(Haft and Tovchigrechko, 2012). 감염성 질병 진단을 위해서는 병원균의 특정 균종 을 동정하고 유전적 변이 균주의 존재 등을 검사하지만, 법미생물학 분석 기법은 미생물군집의 프로파일을 조사하 게 된다. 가장 유익한 미생물군집 마커 패널을 사용하여 표적화된 증균 및 염기서열 결정 분석법은 미생물군집 프 로파일링을 통해 법의학적 개인 식별을 위한 이상적인 솔 루션을 제공하여 안정적인 정보 사이트에서 높은 적용 범 위를 얻을 수 있을 것이다.

법정에서 법미생물학 증거가 채택되려면, 미생물 시 료의 채취, 분석 및 결과 해석을 위한 표준 작업 절차 (standard operating procedures; SOPs)의 개발이 필요하다. 또 한 세균학적 분석결과의 정확성을 증명하기 위해 진단검 사 실험실에서 채택하고 있는 정도 관리 $(\mathrm{QC})$ 와 품질 보 증(QA)도 필요할 것이다(Pitt and Cunningham, 2009). 법원 에서 법미생물학 증거의 허용 가능성은 관련 국가의 법 적 틀에 따를 것이다. 예를 들어, 미국에서는 'Daubert 표 준'이 법정에서 과학적 증거의 허용 가능성을 관리한다. Daubert 표준을 충족시키기 위해서는 알려진 오류율을 갖 는 표준화되고 검증된 프로토콜을 사용하여 증거물을 채 취하여야 한다. 또한 절차는 동료 평가를 거친 후에 출판 되어야 하며 적절한 과학 공동체가 '일반적으로 받아들일 수 있는' 것으로 간주되어야 한다(Harmon, 2005).

법미생물학적 분석 기법을 과학수사 현장에 적용하기 전에 상당한 유효성 평가와 오랜 기간의 개선 과정을 필 요로 한다. 또한 법미생물학적 분석 기법이 기존의 표준 화되어 널리 사용되고 있는 과학수사 기법보다 얼마나 정 
확한지 비교하는 연구가 필요하며, 피부 연관 미생물군집 의 광범위한 유전체 분석 데이터베이스 및 증거물에서 충 분히 많은 수의 미생물군집 분석, 그리고 단순 접촉 증거 물에서 미생물군집 분석만으로도 개인 식별이 가능하도록 추가적인 연구가 필요하다. 법미생물학은 다양한 범죄 수 사에 엄청난 잠재력을 제공하지만, 합리적인 충분한 시간 간격으로 수집된 샘플에 대해 높은 분류 정확도를 생성하 는 피부 미생물군집의 안정된 특징을 확인하는 연구가 필 요하다. 미생물군집의 프로파일 분석을 법과학적으로 적 용하는 잠재성을 밝혀내고 이를 실현하기 위해서는 많은 기초 연구가 추가적으로 필요할 것으로 사료된다. 상기한 바와 같이 법미생물학적 분석기법은 아직까지 추가적인 연구와 유효성 평가가 필요함에도 불구하고, 범죄의 지능 화 첨단화로 인해 범인들이 더 이상 사건 현장에 지문뿐 만 아니라 DNA 시료가 될 만한 혈액, 타액, 정액, 기타 체액 등을 남기지 않으려는 상황에서 미세 증거물이 될 수 있는 미생물의 법미생물학적 분석은 필수 불가결하다. 미해결 과제의 방지와 인권보장, 증거재판주의에 따른 합 리적 의심의 여지가 없는 증거 분석을 위한 법미생물학의 중요성과 필요성은 증대될 것으로 사료된다.

\section{ACKNOWLEDGEMENT}

This research was supported by the Soonchunhyang University Research Fund and by Basic Science Research Program through the National Research Foundation of Korea (NRF) funded by the Ministry of Education (NRF-2017R1D1A1B03032960).

\section{CONFLICT OF INTEREST}

No potential conflict of interest relevant to this article was reported.

\section{REFERENCES}

Aas JA, Paster BJ, Stokes LN, Olsen I, Dewhirst FE. Defining the normal bacterial flora of the oral cavity. J Clin Microbiol. 2005. 43: 5721-5732.

Adekambi T, Colson P, Drancourt M. rpoB-based identification of nonpigmented and late-pigmenting rapidly growing mycobacteria. J Clin Microbiol. 2003. 41: 5699-5708.

Ahn J, Yang L, Paster BJ, Ganly I, Morris L, Pei Z, Hayes RB. Oral microbiome profiles: 16S rRNA pyrosequencing and microarray assay comparison. PLoS One. 2011. 6: e22788.

Akutsu T, Motani H, Watanabe K, Iwase H, Sakurada K. Detection of bacterial 16S ribosomal RNA genes for forensic identification of vaginal fluid. Leg Med (Tokyo). 2012. 14: 160-162.

Alan G, Sarah JP. Microbes as forensic indicators. Trop Biomed. 2012. 29: 311-330.

Bai G, Gajer P, Nandy M, Ma B, Yang H, Sakamoto J, Blanchard MH, Ravel J, Brotman RM. Comparison of storage conditions for human vaginal microbiome studies. PLoS One. 2012. 7 : e36934.

Benschop CC, Quaak FC, Boon ME, Sijen T, Kuiper I. Vaginal microbial flora analysis by next generation sequencing and microarrays; can microbes indicate vaginal origin in a forensic context? Int J Legal Med. 2012. 126: 303-310.

Bizzarro S, Loos BG, Laine ML, Crielaard W, Zaura E. Subgingival microbiome in smokers and non-smokers in periodontitis: An exploratory study using traditional targeted techniques and a next-generation sequencing. J Clin Periodontol. 2013. 40: 483 -492 .

Blaser MJ. Harnessing the power of the human microbiome. Proc Natl Acad Sci U S A. 2010. 107: 6125-6126.

Bokulich NA, Chung J, Battaglia T, Henderson N, Jay M, Li H, A DL, Wu F, Perez-Perez GI, Chen Y, Schweizer W, Zheng X, Contreras M, Dominguez-Bello MG, Blaser MJ. Antibiotics, birth mode, and diet shape microbiome maturation during early life. Sci Transl Med. 2016. 8: 343ra382.

Boor KJ, Duncan ML, Price CW. Genetic and transcriptional organization of the region encoding the beta subunit of Bacillus subtilis RNA polymerase. J Biol Chem. 1995. 270: 20329-20336.

Borgula LM, Robinson FG, Rahimi M, Chew KE, Birchmeier KR, Owens SG Kieser JA, Tompkins GR. Isolation and genotypic comparison of oral streptococci from experimental bitemarks. J Forensic Odontostomatol. 2003. 21: 23-30.

Brandwein M, Fuks G, Israel A, Al-Ashhab A, Nejman D, Straussman R, Hodak E, Harari M, Steinberg D, Bentwich Z, Shental N, Meshner S. Temporal stability of the healthy human skin microbiome following dead sea climatotherapy. Acta Derm Venereol. 2018. 98: 256-261.

Brooke JS, Annand JW, Hammer A, Dembkowski K, Shulman ST. Investigation of bacterial pathogens on 70 frequently used environmental surfaces in a large urban U.S. university. J Environ Health. 2009. 71: 17-22.

Brown KA, Elliot TR, Rogers AH, Thonard JC. The survival of oral streptococci on human skin and its implication in bitemark investigation. Forensic Sci Int. 1984. 26: 193-197.

Budowle B, Allard MW, Wilson MR, Chakraborty R. Forensics and mitochondrial DNA: Applications, debates, and foundations. 
Annu Rev Genomics Hum Genet. 2003. 4: 119-141.

Budowle B, Schutzer S, Breeze R, Keim P, Morse S. Microbial Forensic. Elsevier, Amsterdam, Holland. 2010. $2^{\text {nd }}$ edition. 561 -580 .

Can I, Javan GT, Pozhitkov AE, Noble PA. Distinctive thanatomicrobiome signatures found in the blood and internal organs of humans. J Microbiol Methods. 2014. 106: 1-7.

Capone KA, Dowd SE, Stamatas GN, Nikolovski J. Diversity of the human skin microbiome early in life. J Invest Dermatol. 2011. 131: 2026-2032.

Caporaso JG, Lauber CL, Costello EK, Berg-Lyons D, Gonzalez A, Stombaugh J, Knights D, Gajer P, Ravel J, Fierer N, Gordon JI, Knight R. Moving pictures of the human microbiome. Genome Biol. 2011. 12: R50.

Casarin RC, Barbagallo A, Meulman T, Santos VR, Sallum EA, Nociti FH, Duarte PM, Casati MZ, Goncalves RB. Subgingival biodiversity in subjects with uncontrolled type-2 diabetes and chronic periodontitis. J Periodontal Res. 2013. 48: 30-36.

Case RJ, Boucher Y, Dahllof I, Holmstrom C, Doolittle WF, Kjelleberg S. Use of 16S rRNA and rpoB genes as molecular markers for microbial ecology studies. Appl Environ Microbiol. 2007. 73: 278-288.

Cho I, Blaser MJ. The human microbiome: At the interface of health and disease. Nat Rev Genet. 2012. 13: 260-270.

Costello EK, Lauber CL, Hamady M, Fierer N, Gordon JI, Knight R. Bacterial community variation in human body habitats across space and time. Science. 2009. 326: 1694-1697.

Damann FE, Williams DE, Layton AC. Potential use of bacterial community succession in decaying human bone for estimating postmortem interval. J Forensic Sci. 2015. 60: 844-850.

David LA, Maurice CF, Carmody RN, Gootenberg DB, Button JE, Wolfe BE, Ling AV, Devlin AS, Varma Y, Fischbach MA, Biddinger SB, Dutton RJ, Turnbaugh PJ. Diet rapidly and reproducibly alters the human gut microbiome. Nature. 2014. 505: 559-563.

Donaldson AE, Taylor MC, Cordiner SJ, Lamont IL. Using oral microbial DNA analysis to identify expirated bloodspatter. Int J Legal Med. 2010. 124: 569-576.

Faith JJ, Guruge JL, Charbonneau M, Subramanian S, Seedorf H, Goodman AL, Clemente JC, Knight R, Heath AC, Leibel RL, Rosenbaum M, Gordon JI. The long-term stability of the human gut microbiota. Science. 2013. 341: 1237439.

Fierer N, Hamady M, Lauber CL, Knight R. The influence of sex, handedness, and washing on the diversity of hand surface bacteria. Proc Natl Acad Sci U S A. 2008. 105: 17994-17999.
Fierer N, Lauber CL, Zhou N, McDonald D, Costello EK, Knight R. Forensic identification using skin bacterial communities. Proc Natl Acad Sci U S A. 2010. 107: 6477-6481.

Fleming RI, Harbison S. The use of bacteria for the identification of vaginal secretions. Forensic Sci Int Genet. 2010. 4: 311-315.

Flores GE, Bates ST, Knights D, Lauber CL, Stombaugh J, Knight R, Fierer N. Microbial biogeography of public restroom surfaces. PLoS One. 2011. 6: e28132.

Franzosa EA, Huang K, Meadow JF, Gevers D, Lemon KP, Bohannan BJ, Huttenhower C. Identifying personal microbiomes using metagenomic codes. Proc Natl Acad Sci U S A. 2015. 112: E2930-2938.

Fredricks DN. Microbial ecology of human skin in health and disease. J Investig Dermatol Symp Proc. 2001. 6: 167-169.

Gardner RM. Practical crime scene processing and investigation. 2012. CRC Press. Boca Raton, FL.

Giovannoni SJ, Britschgi TB, Moyer CL, Field KG. Genetic diversity in Sargasso Sea bacterioplankton. Nature. 1990. 345: 60 $-63$.

Greenbaum D, Sboner A, Mu XJ, Gerstein M. Genomics and privacy: Implications of the new reality of closed data for the field. PLoS Comput Biol. 2011. 7: e1002278.

Greenblum S, Turnbaugh PJ, Borenstein E. Metagenomic systems biology of the human gut microbiome reveals topological shifts associated with obesity and inflammatory bowel disease. Proc Natl Acad Sci U S A. 2012. 109: 594-599.

Grice EA, Kong HH, Conlan S, Deming CB, Davis J, Young AC, Program NCS, Bouffard GG, Blakesley RW, Murray PR, Green ED, Turner ML, Segre JA. Topographical and temporal diversity of the human skin microbiome. Science. 2009. 324: 1190 -1192 .

Gunn A. Essential forensic biology. 2018. John Wiley \& Sons. Hoboken, NJ.

Gunn A, Pitt SJ. Microbes as forensic indicators. Trop Biomed. 2012. 29: 311-330.

Haft DH, Tovchigrechko A. High-speed microbial community profiling. Nat Methods. 2012. 9: 793-794.

Hale VL, Tan CL, Knight R, Amato KR. Effect of preservation method on spider monkey (Ateles geoffroyi) fecal microbiota over 8 weeks. J Microbiol Methods. 2015. 113: 16-26.

Handelsman J. Metagenomics: Application of genomics to uncultured microorganisms. Microbiol Mol Biol Rev. 2004. 68: 669 -685 .

Harmon R.Microbial forensics. 2005. 382-392. Elsevier/Academic Press. Amsterdam; Boston. 
Human Microbiome Project C. Structure, function and diversity of the healthy human microbiome. Nature. 2012. 486: 207-214.

James SH, Kish PE, Sutton TP. Principles of bloodstain pattern analysis: Theory and practice. 2005. CRC. Boca Raton, Fla.

Jernigan DB, Raghunathan PL, Bell BP, Brechner R, Bresnitz EA, Butler JC, Cetron M, Cohen M, Doyle T, Fischer M, Greene C, Griffith KS, Guarner J, Hadler JL, Hayslett JA, Meyer R, Petersen LR, Phillips M, Pinner R, Popovic T, et al. Investigation of bioterrorism-related anthrax, United States, 2001: Epidemiologic findings. Emerg Infect Dis. 2002. 8: 1019-1028. Jespers V, Menten J, Smet H, Poradosu S, Abdellati S, Verhelst R, Hardy L, Buve A, Crucitti T. Quantification of bacterial species of the vaginal microbiome in different groups of women, using nucleic acid amplification tests. BMC Microbiol. 2012. 12: 83 .

Kort R, Caspers M, van de Graaf A, van Egmond W, Keijser B, Roeselers G. Shaping the oral microbiota through intimate kissing. Microbiome. 2014. 2: 41.

La Scola B, Bui LT, Baranton G, Khamis A, Raoult D. Partial rpoB gene sequencing for identification of Leptospira species. FEMS Microbiol Lett. 2006. 263: 142-147.

Lamont RF, Sobel JD, Akins RA, Hassan SS, Chaiworapongsa T, Kusanovic JP, Romero R. The vaginal microbiome: New information about genital tract flora using molecular based techniques. BJOG. 2011. 118: 533-549.

Lazarevic V, Manzano S, Gaia N, Girard M, Whiteson K, Hibbs J, Francois P, Gervaix A, Schrenzel J. Effects of amoxicillin treatment on the salivary microbiota in children with acute otitis media. Clin Microbiol Infect. 2013. 19: E335-342.

Lazarevic V, Whiteson K, Hernandez D, Francois P, Schrenzel J. Study of inter- and intra-individual variations in the salivary microbiota. BMC Genomics. 2010. 11: 523.

Lazarevic V, Whiteson K, Huse S, Hernandez D, Farinelli L, Osteras M, Schrenzel J, Francois P. Metagenomic study of the oral microbiota by illumina high-throughput sequencing. J Microbiol Methods. 2009. 79: 266-271.

Leake SL, Pagni M, Falquet L, Taroni F, Greub G. The salivary microbiome for differentiating individuals: Proof of principle. Microbes Infect. 2016. 18: 399-405.

Lee SY, Eom YB. Analysis of microbial composition associtated with freshwater and seawater. Biomed Sci Let. 2016. 22: 150 -159 .

Lemon KP, Klepac-Ceraj V, Schiffer HK, Brodie EL, Lynch SV, Kolter R. Comparative analyses of the bacterial microbiota of the human nostril and oropharynx. MBio. 2010. 1: e00129-10.
Lenz EJ, Foran DR. Bacterial profiling of soil using genus-specific markers and multidimensional scaling. J Forensic Sci. 2010. 55: 1437-1442.

Li K, Bihan M, Yooseph S, Methe BA. Analyses of the microbial diversity across the human microbiome. PLoS One. 2012. 7: e32118.

Lin Z, Owen AB, Altman RB. Genetics. Genomic research and human subject privacy. Science. 2004. 305: 183.

Lowrance WW, Collins FS. Ethics. Identifiability in genomic research. Science. 2007. 317: 600-602.

Ma J, Coarfa C, Qin X, Bonnen PE, Milosavljevic A, Versalovic J, Aagaard K. mtDNA haplogroup and single nucleotide polymorphisms structure human microbiome communities. BMC Genomics. 2014. 15: 257.

MacConaill L, Meyerson M. Adding pathogens by genomic subtraction. Nat Genet. 2008. 40: 380-382.

Macdonald CA, Ang R, Cordiner SJ, Horswell J. Discrimination of soils at regional and local levels using bacterial and fungal T-RFLP profiling. J Forensic Sci. 2011. 56: 61-69.

Malik P, Singh G. Health considerations for forensic professionals: A review. Forensic Science Policy \& Management. An International Journal. 2011. 2: 1-4.

Mayntz-Press KA, Sims LM, Hall A, Ballantyne J. Y-STR profiling in extended interval ( $>$ or $=3$ days) postcoital cervicovaginal samples. J Forensic Sci. 2008. 53: 342-348.

Misic AM, Davis MF, Tyldsley AS, Hodkinson BP, Tolomeo P, Hu B, Nachamkin I, Lautenbach E, Morris DO, Grice EA. The shared microbiota of humans and companion animals as evaluated from Staphylococcus carriage sites. Microbiome. 2015. 3: 2 .

Mollet C, Drancourt M, Raoult D. $r p o B$ sequence analysis as a novel basis for bacterial identification. Mol Microbiol. 1997. 26: $1005-1011$

Moon JH, Lee JH, Lee JY. Subgingival microbiome in smokers and non-smokers in korean chronic periodontitis patients. Mol Oral Microbiol. 2015. 30: 227-241.

Moreno LI, Mills D, Fetscher J, John-Williams K, Meadows-Jantz L, McCord B. The application of amplicon length heterogeneity PCR (LH-PCR) for monitoring the dynamics of soil microbial communities associated with cadaver decomposition. J Microbiol Methods. 2011. 84: 388-393.

Moreno LI, Mills DK, Entry J, Sautter RT, Mathee K. Microbial metagenome profiling using amplicon length heterogeneitypolymerase chain reaction proves more effective than elemental analysis in discriminating soil specimens. J Forensic Sci. 
2006. 51: 1315-1322.

Nakamura S, Maeda N, Miron IM, Yoh M, Izutsu K, Kataoka C, Honda T, Yasunaga T, Nakaya T, Kawai J, Hayashizaki Y, Horii T, Iida T. Metagenomic diagnosis of bacterial infections. Emerg Infect Dis. 2008. 14: 1784-1786.

Nakanishi H, Kido A, Ohmori T, Takada A, Hara M, Adachi N, Saito K. A novel method for the identification of saliva by detecting oral streptococci using PCR. Forensic Sci Int. 2009. 183: $20-23$.

Nikhil GN, Venkata Mohan S, Swamy YV. Systematic approach to assess biohydrogen potential of anaerobic sludge and soil rhizobia as biocatalysts: Influence of crucial factors affecting acidogenic fermentation. Bioresour Technol. 2014. 165: 323 -331 .

Oh J, Byrd AL, Park M, Program NCS, Kong HH, Segre JA. Temporal stability of the human skin microbiome. Cell. 2016. 165: 854-866.

Pallen MJ, Loman NJ. Are diagnostic and public health bacteriology ready to become branches of genomic medicine? Genome Med. 2011. 3: 53.

Paster BJ, Olsen I, Aas JA, Dewhirst FE. The breadth of bacterial diversity in the human periodontal pocket and other oral sites. Periodontol. 2000. 2006. 42: 80-87.

Pfeiffer H, Huhne J, Ortmann C, Waterkamp K, Brinkmann B. Mitochondrial DNA typing from human axillary, pubic and head hair shafts - success rates and sequence comparisons. Int J Legal Med. 1999. 112: 287-290.

Pitt SJ, Cunningham JM. An Introduction to Biomedical Science in Clinical and Professional Practice. Wiley-Blackwell, Chichester, UK. 2009. 88-97.

Power DA, Cordiner SJ, Kieser JA, Tompkins GR, Horswell J. PCR-based detection of salivary bacteria as a marker of expirated blood. Sci Justice. 2010. 50: 59-63.

Qin J, Li R, Raes J, Arumugam M, Burgdorf KS, Manichanh C, Nielsen T, Pons N, Levenez F, Yamada T, Mende DR, Li J, Xu J, Li S, Li D, Cao J, Wang B, Liang H, Zheng H, Xie Y, et al. A human gut microbial gene catalogue established by metagenomic sequencing. Nature. 2010. 464: 59-65.

Quaak FC, Kuiper I. Statistical data analysis of bacterial T-RFLP profiles in forensic soil comparisons. Forensic Sci Int. 2011. 210: 96-101.

Rabe LK, Winterscheid KK, Hillier SL. Association of viridans group streptococci from pregnant women with bacterial vaginosis and upper genital tract infection. J Clin Microbiol. 1988. 26: 1156-1160.
Rahimi M, Heng NC, Kieser JA, Tompkins GR. Genotypic comparison of bacteria recovered from human bite marks and teeth using arbitrarily primed PCR. J Appl Microbiol. 2005. 99: 1265-1270.

Rajendhran J, Gunasekaran P. Microbial phylogeny and diversity: Small subunit ribosomal RNA sequence analysis and beyond. Microbiol Res. 2011. 166: 99-110.

Ravel J, Gajer P, Abdo Z, Schneider GM, Koenig SS, McCulle SL, Karlebach S, Gorle R, Russell J, Tacket CO, Brotman RM, Davis CC, Ault K, Peralta L, Forney LJ. Vaginal microbiome of reproductive-age women. Proc Natl Acad Sci U S A. 2011. 108 Suppl 1: 4680-4687.

Read TD, Salzberg SL, Pop M, Shumway M, Umayam L, Jiang L, Holtzapple E, Busch JD, Smith KL, Schupp JM, Solomon D, Keim P, Fraser CM. Comparative genome sequencing for discovery of novel polymorphisms in Bacillus anthracis. Science. 2002. 296: 2028-2033.

Redondo-Lopez V, Cook RL, Sobel JD. Emerging role of lactobacilli in the control and maintenance of the vaginal bacterial microflora. Rev Infect Dis. 1990. 12: 856-872.

Ritz K, Dawson L, Miller D.Criminal and environmental soil forensics. 2009. Springer. Berlin ; New York.

Rodriguez LL, Brooks LD, Greenberg JH, Green ED. Research ethics. The complexities of genomic identifiability. Science. 2013. 339: 275-276.

Rudney JD, Larson CJ. Use of restriction fragment polymorphism analysis of rRNA genes to assign species to unknown clinical isolates of oral viridans streptococci. J Clin Microbiol. 1994. 32: 437-443.

Ruffell A. Forensic pedology, forensic geology, forensic geoscience, geoforensics and soil forensics. Forensic Sci Int. 2010. 202: 9-12.

Savage DC. Microbial ecology of the gastrointestinal tract. Annu Rev Microbiol. 1977. 31: 107-133.

Schloissnig S, Arumugam M, Sunagawa S, Mitreva M, Tap J, Zhu A, Waller A, Mende DR, Kultima JR, Martin J, Kota K, Sunyaev SR, Weinstock GM, Bork P. Genomic variation landscape of the human gut microbiome. Nature. 2013. 493: 45-50.

Schmedes SE, Woerner AE, Novroski NMM, Wendt FR, King JL, Stephens KM, Budowle B. Targeted sequencing of cladespecific markers from skin microbiomes for forensic human identification. Forensic Sci Int Gent. 2018. 32: 50-61.

Schmedes SE, Sajantila A, Budowle B. Expansion of microbial forensics. J Clin Microbiol. 2016. 54: 1964-1974.

Segata N, Waldron L, Ballarini A, Narasimhan V, Jousson O, 
Huttenhower C. Metagenomic microbial community profiling using unique clade-specific marker genes. Nat Methods. 2012. 9: 811-814.

Sender R, Fuchs S, Milo R. Revised estimates for the number of human and bacteria cells in the body. PLoS Biol. 2016. 14: e1002533.

Smalla K, Oros-Sichler M, Milling A, Heuer H, Baumgarte S, Becker R, Neuber G, Kropf S, Ulrich A, Tebbe CC. Bacterial diversity of soils assessed by DGGE, T-RFLP and SSCP fingerprints of PCR-amplified 16S rRNA gene fragments: Do the different methods provide similar results? J Microbiol Methods. 2007. 69: 470-479.

Smith SM, Eng RH, Padberg FT, Jr. Survival of nosocomial pathogenic bacteria at ambient temperature. J Med. 1996. 27: 293 $-302$.

Song SJ, Lauber C, Costello EK, Lozupone CA, Humphrey G, Berg-Lyons D, Caporaso JG, Knights D, Clemente JC, Nakielny S, Gordon JI, Fierer N, Knight R. Cohabiting family members share microbiota with one another and with their dogs. Elife. 2013. 2: e00458.

Stahringer SS, Clemente JC, Corley RP, Hewitt J, Knights D, Walters WA, Knight R, Krauter KS. Nurture trumps nature in a longitudinal survey of salivary bacterial communities in twins from early adolescence to early adulthood. Genome Res. 2012. 22: 2146-2152.

Sweet D, Lorente JA, Valenzuela A, Lorente M, Villanueva E. PCRbased DNA typing of saliva stains recovered from human skin. J Forensic Sci. 1997. 42: 447-451.

Sweet D, Pretty IA. A look at forensic dentistry--part 2: Teeth as weapons of violence--identification of bitemark perpetrators. Br Dent J. 2001. 190: 415-418.

Tagg JR and Ragland NL. Application of BLIS typing to studies of the survival on surfaces of salivary streptococci and staphyloccci. J Appl Bacteriol. 1991. 71: 339-42.

Tibbett M, Carter DO. Soil analysis in forensic taphonomy: Chemical and biological effects of buried human remains. 2008. CRC Press. Boca Raton.

Torsvik V, Goksøyr J, Daae FL. High diversity in DNA of soil bacteria. Applied and environmental microbiology. 1990. 56: 782-787.

Tridico SR, Murray DC, Addison J, Kirkbride KP, Bunce M. Metagenomic analyses of bacteria on human hairs: A qualitative assessment for applications in forensic science. Investig Genet. 2014. 5: 16

Turnbaugh PJ, Hamady M, Yatsunenko T, Cantarel BL, Duncan A,
Ley RE, Sogin ML, Jones WJ, Roe BA, Affourtit JP, Egholm M, Henrissat B, Heath AC, Knight R, Gordon JI. A core gut microbiome in obese and lean twins. Nature. 2009. 457: 480 -484 .

Turnbaugh PJ, Ley RE, Hamady M, Fraser-Liggett CM, Knight R, Gordon JI. The human microbiome project. Nature. 2007. 449: 804-810.

Weisburg WG, Barns SM, Pelletier DA, Lane DJ. 16S ribosomal DNA amplification for phylogenetic study. J Bacteriol. 1991. 173: 697-703.

Wilkins D, Leung MH, Lee PK. Microbiota fingerprints lose individually identifying features over time. Microbiome. 2017. 5: 1 .

Williams DW, Gibson G. Individualization of pubic hair bacterial communities and the effects of storage time and temperature. Forensic Sci Int Genet. 2017. 26: 12-20.

Wisplinghoff H, Reinert RR, Cornely O, Seifert H. Molecular relationships and antimicrobial susceptibilities of viridans group streptococci isolated from blood of neutropenic cancer patients. J Clin Microbiol. 1999. 37: 1876-1880.

Wu GD, Chen J, Hoffmann C, Bittinger K, Chen YY, Keilbaugh SA, Bewtra M, Knights D, Walters WA, Knight R, Sinha R, Gilroy E, Gupta K, Baldassano R, Nessel L, Li H, Bushman FD, Lewis JD. Linking long-term dietary patterns with gut microbial enterotypes. Science. 2011. 334: 105-108.

Yaegaki K, Sakata T, Ogura R, Kameyama T, Sujaku C. Influence of aging on DNase activity in human parotid saliva. J Dent Res. 1982. 61: 1222-1224.

Yasunenko T, Rey FE, Manary MJ, Trehan I, Dominguez-Bello MG, Contreras M, Magris M, Hidalgo G, Baldassano RN, Anokhin AP, Heath AC, Warner B, Reeder J, Kuczynski J, Caporaso JG, Lozupone CA, Lauber C, Clemente JC, Knights D, Knight $\mathrm{R}$, et al. Human gut microbiome viewed across age and geography. Nature. 2012. 486: 222-227.

Zala K. Forensic science. Dirty science: Soil forensics digs into new techniques. Science. 2007. 318: 386-387.

Zaura E, Keijser BJ, Huse SM, Crielaard W. Defining the healthy "core microbiome" of oral microbial communities. BMC Microbiol. 2009. 9: 259 .

https://doi.org/10.15616/BSL.2018.24.4.292

Cite this article as: Eom YB. Microbial Forensics: Human Identification. Biomedical Science Letters. 2018. 24: 292-304. 